\title{
CAPACITANCE-BASED TIREN CHICKEN MEAT DETECTOR GLOVE AS CHICKEN MEAT SAFETY SOLUTION IN INDONESIA
}

\author{
RHEGY PRATIDINA ISKANDAR ${ }^{1}$, MUHAMMAD ADAM ALFATH ${ }^{2}$, IMAN HERNAMAN ${ }^{1}$, \\ CUKUP MULYANA*2 \\ ${ }^{1}$ Animal Product Technology, Animal husbandry Faculty of Universitas Padjadjaran \\ ${ }^{2}$ Departemen Fisika Fakultas MIPA Universitas Padjadjaran, \\ Jl. Raya Bandung-Sumedang Km 21, Jatinangor 45363 \\ *email : cukup.mulyana@phys.unpad.ac.id
}

\begin{abstract}
Abstrak. Banyak produk pangan Indonesia yang tidak aman untuk dikonsumsi sehingga dapat menimbulkan masalah kesehatan kepada konsumen. Salah satunya adalah daging ayam yang dijual di pasar tradisional. Daging ayam ini biasa tercampur dengan daging ayam tiren. Daging ayam tiren merupakan ayam yang mati tidak melalui proses penyembelihan yang benar sehingga darah mengendap di dalamnya dan mengandung uric acid yang merupakan racun berbahaya bagi kesehatan. Metode yang dilakukan dalam karya tulis ini adalah studi pustaka dan observasi lapangan. Perkembangan teknologi dapat diminimalisasi dengan dibuanya sebuah inovasi yaitu sarung tangan pendeteksi daging ayam tiren. Sarung tangan ini dirancang menggunakan alat sensor guna mendeteksi daging ayam tiren. Sarung ini terdiri dari 2 bagian utama yaitu bagian sensor dan indikator. Bagian sensor yang berupa probe tertanam di sebuah sarung tangan yang akan bersentuhan dengan daging. Nilai kapasitansi daging ayam tiren lebih besar dari daging ayam normal. Nilai kapasitansi daging nantinya akan terbaca oleh mikrokontroler dan dapat dibedakan nilai kapasitasnya. Sarung tangan akan menyentuh daging ayam, sehingga sensor akan memberikan sinyal yang menjadi input kapasitansi. Serta indikator akan memberikan respon warna lampu merah pada daging ayam yang positif tiren dan warna lampu hijau untuk daging ayam segar. Adanya sarung tangan ini maka permasalahan konsumen memperoleh daging ayam tiren dapat diminimalisasi, para pedagang yang menjual daging ayam tiren dapat diatasi, serta mencegah timbulnya masalah penyakit pada konsumen daging ayam di Indonesia.
\end{abstract}

Kata kunci : kapasitansi, sarung tangan, daging ayam tiren

Abstract. Many food products in Indonesia are not safe for consumption. This food can cause health problems to consumers. One of the unsafe food is chicken meat in traditional market. There is a case that chicken meat mixed with bad chicken meat called tiren chicken. Tiren chicken is a chicken that died not through the correct process of slaughtering or dead before being slaughtered. Hence, the blood of tiren chicken meat contains uric acid which is a dangerous poison for human health. The methods used in this paper is a literature study. The development of technology can minimize this problem by making an innovation, for example tiren chicken gloves detector. The glove was designed using the sensor (probe) to detect tiren chicken. This glove is comprised of two main parts. Those are sensor (probe) and indicators. The sensor (probe) embedded in a glove that will be used to touch the chicken meat. The capacitance value of good chicken meat bigger from tiren chicken meat. The value of capacitance chicken meat will be detected by a microcontroller and obtained value of the specified capacitance. When the gloves touch the chicken meat, the sensor (probe) will produce a signal being input capacitance. Indicators will give a response: red light color for positive tiren chicken meat and the green light color for normal chicken meat. The existence of this glove can minimize costumer problems by detecting the tiren chicken meat. Then problem about 
tiren chicken meat sellers can be resolved, and can preventing consumers from disease caused by consumption of chicken meat in Indonesia.

Keywords : capacitance, gloves, tiren chicken meat

\section{Pendahuluan}

Almost of all Indonesian communities like chicken food. Chicken meat is liked because it can be cooked into various types of foods, the numbers that much, and the price is reasonable. But the currently problem in Indonesia is low food safety applied by traders in traditional markets. Many cases of the sale of chicken meat which is not feasible as sale of tiren chicken meat. Tiren Chicken (mati kemarin) or carcass chicken is chicken that does not through the process of good slaughter. Tiren chicken meat does not through good slaughter so that the three channels on the neck of the chicken (gastrointestinal tract, respiratory tract, and blood vessels) are not cut off completely. This causes the blood do not out from the body and the blood settles on the meat. The blood settles in the meat will be a source of nutrients for the growth of microorganisms (bacteria, viruses, and fungus) faster. This causes problem to consumer health who consume it.

Food safety that must be applied in Indonesia must fulfill the criteria of safe, healthy, whole, and halal (SHWH). The Government's policy of providing meat that is SHWH with the objective of protecting public health and inner peace of mind guarantee society. As for the meat in question was: safe i.e. meat does not contain the danger of chemical and physical biology, which can lead to disease and disrupt human health; healthy i.e. meat have substances that are needed and useful to the health and growth of the human body; whole i.e. not meat mixed with parts of other animals; and halal i.e. animals or their meat is slaughtered and handled in accordance of Islamic jurisprudence (The Ministry of Agriculture, 2012). Tiren chicken meat which is sold in traditional markets surely don't fulfill the criteria of SHWH because: tiren chicken contain dangers that can lead to disease and disrupt human health; substances that your body needs on tiren chicken meat damaged; chicken meat mixed with tiren chicken meat, tiren chicken meat is not halal because the meat not slaughtered and not handled according of Islamic jurisprudence.

Tiren chicken meat sales in traditional markets are banned because that would be detrimental to consumers. Government through legislation of criminal law (KUHP) Article 501 paragraph 1 States the party authorities would catch the perpetrators (trader) sells goods damaged or carrion (tiren). Islam forbids such things because of the elements of fraud and the sale of meat are not halal. In accordance with the Hadith, the mother of Syihad "that Ubeidullah Ibn 'Abd convey to him that Abdullah ibn Abbas told him that the Prophet passed on a goat that has become the carcass, and then he said: "why do not you capitalize on his skin?" They said, "it was a wreck." Then his words were: "the unlawful it is just eat it!" (Narrated by AlBukhari Muslim). Tiren chicken meat should be utilized, but cannot be sold or consumed because it contains elements of fraud and not in accordance with the criteria of SHWH. Meat is one of the farm products that is composed of a network of animal and can be processed so that it can be consumed, without interfering with the body's health. Chicken has a complete nutrient content and high protein. Chicken meat has a lot of good nutrition for health due to the presence of essential amino acids are complete and balanced, water, carbohydrates, and inorganic 
components (Soeparno, 2009). Tiren chicken meat is a chicken not through a process of deduction in accordance with provisions that exist or can be said to has died before the wreck to be slain. The case of buying and selling tiren chicken meat by traders in traditional markets is done by reason of traders can avoid losses because chicken is not sold so that any gains can be obtained. Traders that cheating will be mixing the chicken meat is fresh with tiren chicken meat that does not meet the criteria of SHWH. So many consumers will be harmed because obtaining an unworthy chicken meat consumption. A dead chicken that we often know with tiren chicken (mati kemarin) that is a dead chicken before slain this is due to an assortment of dead getting hit by car, pain, starvation, poisoning, too old or died en route, and died while awaiting execution killed. The chain of trade and marketing chicken pieces still largely through the hands of distributors. This can cause the death of chicken occurs before the slain. Moreover, coupled with a means of shelter, handling and transportation less adequate (Nurkholis, 2009).

Chicken tiren should be avoided, according to the word of Allah SWT in the Quran Surat Al-Baqarah 168, 172, and 173. In addition, the Prophet said in a Hadith narrated by muslim halal Which reads "it is already clear, and no matter whom it was clear; and in between there are things which are musytabihat (syubhat, vague, unclear halal covenants), most people do not know the law. He who carefully from syubhat, really he has saved religion and her self-esteem". Therefore, consumers need to be smart in choosing chicken meat in traditional markets opportunities. But the consumers are difficult generally to distinguish chicken tiren with chicken meat is fresh in traditional market because there are already cut up and mixed together.

Chicken meat is usually sold as a whole or in pieces. Most communities prefer to buy Chicken already cut pieces. That is because not all people fond of all parts of the chicken, the chicken so the purchase already cut up into a solution, there is asection from on the thrown. Part of the usual pieces provided by the trader's chicken pieces including legs, thighs (drumstick), thighs, chestwith ribs, back, and kamip (Dwiatmaja, 2012).

Research on the characteristics of chicken physics tiren and the fresh chicken meat that has been done, the measurement process is done by touching the measuring instrument with the object being measured. This has a disadvantage when made tool detection because the detection tool should come into contact with the object to be detected. Chicken traders usually do not want chicken determining if touched with a tool by prospective buyers.

Based on explanation above, needed a solution to tackle the problem of rampant buying and selling tiren chicken meat by traders who are not responsible. One method that is often applied to the Foundation of the system of detection tiren chicken meat is the way biological and chemical nature by observing the color of chicken meat and observed the tenderness of chicken meat, but this way is relatively expensive. In addition, the difference in the way the value of the capacitance can be relied upon distinction tiren chicken and chicken meat as fresh as research conducted by Frida Agung Rakhmadi, Widayanti Anggar, and Astika Rusma. Therefore, making gloves tiren chicken based capacitance detection is one of the solutions for detecting chicken meat with tiren utilization technologies that are increasingly developing. The gloves are used as media practical use because more and more superior compared to other tools because traders don't want to if he touched the chicken using the tool by consumers. These gloves are also useful to 
cover the hands of consumers of chicken so it does not need to wash your hands after touching the chicken meat. The purpose of this writing is to know the capacitance value of chicken meat and fresh tiren chicken meat, as well as making gauntlets tiren chicken detector.

\section{Metode Penelitian}

Writing method such as: the study of the literature, observation, and field experiments. The cornerstone of the theory of reading the form obtained from the results of research, books, and scholarly articles by searching, recording, an inventory and study to obtain data secondary. Field observation i.e. observation and interviews conducted in person to know the actual state of the meat chicken traders in traditional markets, a chicken slaughterhouse, and a chicken farm. Method study of the literature and observation field used for complementary sources of literature and data required in this writing.

Experiments carried out for 4 months at the Faculty of Animal Husbandry and the Faculty of Mathematics and Natural Sciences of Universitas Padjadjaran, Sumedang, Indonesia. Experiments are conducted to measure the capacitance value of chicken meat and the manufacture of gloves. Measurement of the capacitance value is performed using either a capacitance meter, thin aluminum plates, knives, cutting boards, trays, and plastic. As well as materials in the form of chicken meat and chicken meat fresh tiren. The knife is used to cut the chicken, cutting board for chicken meat trays while cutting, tray for chicken meat, containers and plastic container for dirt. Capacitance meters used to measure capacitance value in parts of chicken meat and chicken meat fresh tiren. Chicken meat is flanked by thin aluminum plates are connected with a capacitance meter. The glove-making is done by using the tool in the form of a sewing tool, scissors, laptops, data cable. As well as materials in the form of gloves made from leather, indicator light color green/red, probe (a thin aluminum plates), cable, and a microcontroller. The gloves are made with store and manage data acquired on a microcontroller using a laptop connected via data cable. Microcontroller that is already saved on the hard-wired parts of gloves. The cable will connect the microcontroller with the probe. At the top of the microcontroller mounted indicator light. Sewing tools used to sew glove.

\section{Hasil dan Pembahasan}

Table 1 and Table 2 show the value of capacitance of tiren chicken is higher than the value of the capacitance of the fresh chicken meat on all parts of the chicken meat. These differences appear to be clearer on the graph of Figure 1.

Table 1. Capacitance value of normal chicken meat

\begin{tabular}{lllllllll}
\hline & \multicolumn{1}{c}{$\mathbf{C}(\boldsymbol{\mu F})$} & $\mathbf{0 . 6 7 7 9}$ & & \multicolumn{1}{c}{$\boldsymbol{C}$} & $\mathbf{0 . 3 5 0 3}$ \\
\hline \multirow{2}{*}{ Part } & \multicolumn{1}{c}{$[\mathbf{C}]$ Capacitance $(\boldsymbol{\mu F})$} & & & & & \\
\cline { 2 - 10 } Thigh & $\mathbf{1}$ & $\mathbf{2}$ & $\mathbf{3}$ & $\mathbf{4}$ & $\mathbf{5}$ & $\mathbf{6}$ & $\mathbf{C}$ & $\boldsymbol{\Delta} \mathbf{C}$ \\
\hline Braest & 0.637 & 0.848 & 0.811 & 0.589 & 0.543 & 0.664 & 0.6367 & 0.1792 \\
\hline Wings & 0.429 & 0.659 & 0.692 & 0.684 & 0.667 & 1.588 & 0.9158 & 0.3980 \\
\hline Head & 1.083 & 0.467 & 0.735 & 0.839 & 0.655 & 0.678 & 0.6617 & 0.1328 \\
\hline Back & 0.677 & 1.520 & 0.559 & 0.665 & 0.727 & 0.970 & 0.8530 & 0.3542 \\
\hline Leg & 0.013 & 0.015 & 0.016 & 0.019 & 0.031 & 0.025 & 0.0198 & 0.0069 \\
\hline
\end{tabular}


Table 2. Capacitance value of tiren chicken meat

\begin{tabular}{|c|c|c|c|c|c|c|c|c|}
\hline \multirow{3}{*}{ Part } & & & & $C(\mu \mathbf{F})$ & 1.0008 & & $\Delta \mathrm{C}$ & 0.3772 \\
\hline & \multicolumn{8}{|c|}{$[\mathrm{C}]$ Capacitance $(\mu \mathrm{F})$} \\
\hline & 1 & 2 & 3 & 4 & 5 & 6 & C & $\Delta \mathbf{C}$ \\
\hline Thigh & 0.846 & 0.771 & 1.003 & 1.087 & 0.712 & 0.732 & 0.85 & 0.1539 \\
\hline Brea & 1.124 & 1.396 & 1.120 & 1.355 & .99 & 1.814 & 1.2998 & 0.2 \\
\hline Wing & 0.821 & 0.834 & 0.785 & 1.002 & 0.962 & .578 & 0.8303 & 0.1501 \\
\hline Head & 1.459 & 1.379 & 1.660 & 1.688 & 0.771 & 1.830 & 1.4645 & 0.3768 \\
\hline Back & 0.494 & 1.978 & 1.091 & 1.382 & 1.136 & 0.721 & 1.1337 & 0.5207 \\
\hline Leg & 0.445 & 0.537 & 0.126 & 0.177 & 0.728 & 0.494 & 0.4178 & 0.2281 \\
\hline
\end{tabular}

A capacitor is an electrical component that consists of two conducting plates is partitioned parallel to each other with an electrical material. This component is very important in electronics or electricity because it has properties: can store an electric charge, can withstand a direct current, and skipped the flow back and forth (Bisman, 2003).

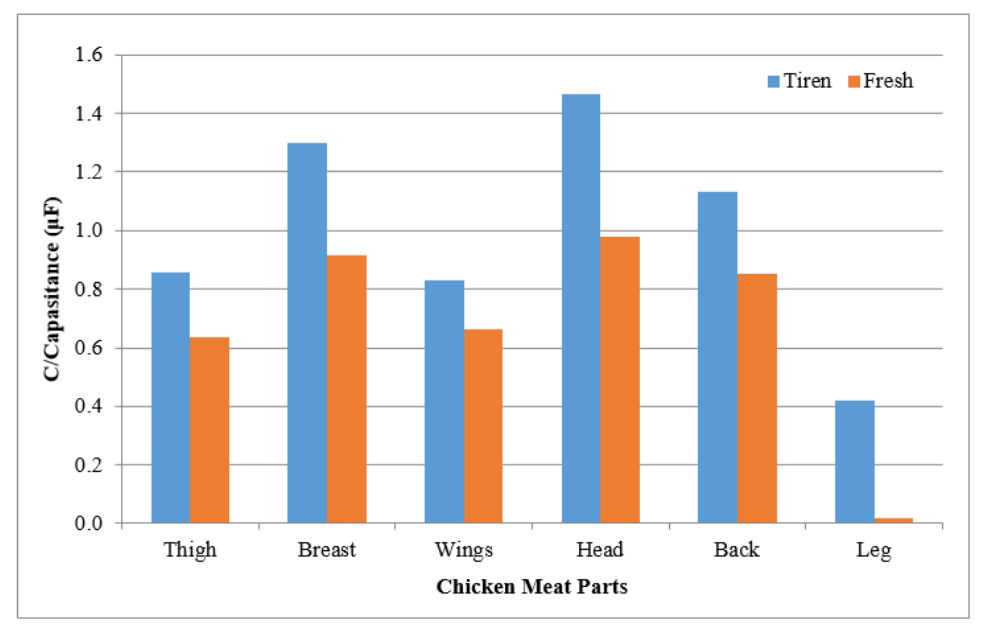

Figure 1. Graph of capacitance value for chicken meat and tiren chicken meat

A parallel plate capacitor with dielectric air and given the voltage of $\mathrm{V}$. The number entered to charge the capacitor is proportional to the voltage provided by the source. Capacitance of a capacitor load represented by the following equation:

$$
C=Q / V
$$

where $\mathrm{C}$ for capacitance value in $\mathrm{F}$ (Farad), $\mathrm{Q}$ for electron charge in $\mathrm{C}$ (Coulomb), and $\mathrm{V}$ for input voltage in $\mathrm{V}$ (Volts).

It appears that the unit of capacitance is the Coulomb/Volt or $(\mathrm{C} / \mathrm{V})$ or the Farad (F). A farad is the amount of electric charge of one coulomb stored in electric (an intermediate substance) with a potential difference of one volt. So the capacitance of a capacitor is the ability of the capacitors to store charge on its plates. Capacitance of a capacitor depends on: dielectric material used, the area of plates, and the distance between the plates (Bisman, 2003). 
The value of capacitance of chicken tiren is bigger than the fresh chicken shows that the size of the storage capacity of charge tiren chicken is bigger than the size of the storage capacity of a fresh chicken charge, so the chicken has tiren permittivity bigger than on a fresh chicken meat. The magnitude of the permittivity chicken tiren when compared to a fresh chicken meat due to the process of decay and decomposition of chemical substances in chicken meat tiren faster than fresh chicken meat. That is because the total microorganisms on meat chicken tiren is more than the fresh chicken (Rakhmadi, 2013).
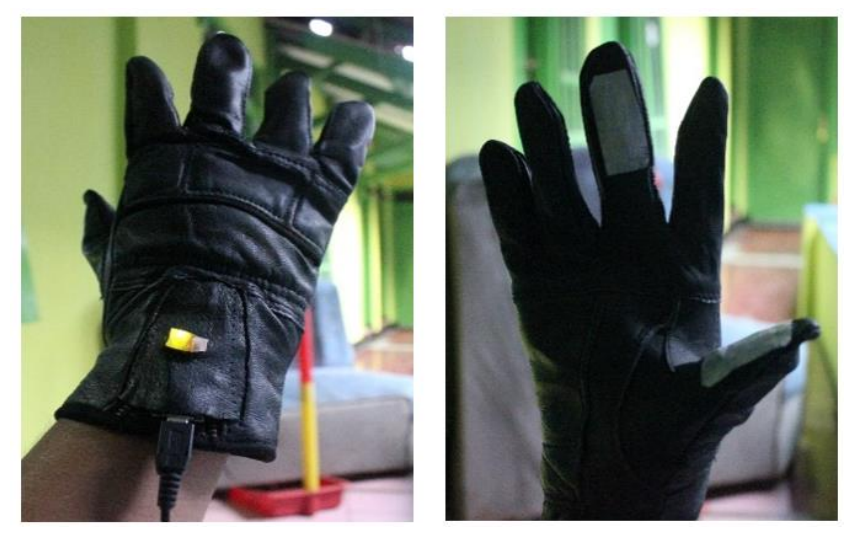

Figure 2. Glove Sensor Capacitance-Based Tiren Chicken Meat (front and back looks)

The difference capacitance value of fresh chicken meat and tiren chicken meat is used as a concept in gloves chicken tiren detector. The bigger the capacitance tiren chicken compared fresh chicken shows that the size of the storage capacity of charge chicken tiren is bigger than the size of the storage capacity of a fresh chicken charge.

With the reference, microcontroller can count and decide whether the chicken tested positive or not with tiren informed through the color of the green light for the fresh chicken and red meat for chicken tiren.

On the gloves that are made there is a sensor (probe) consists of two main parts, namely part of the sensor (probe) and indicators. Part of the probe sensor embedded in a glove that will come into contact with chicken meat. The value of the capacitance of the flesh will be unreadable by a microcontroller and obtained a value of $90 \%$ capacity. Microcontroller is a chip that serves as an electronic circuit controller and keep the program inside. Microcontroller generally consists of a CPU (Central Processing Unit), memory, I/O and supporting units like Analog-to-Digital Converter (ADC) that are already integrated in it. The indicator lamp in the form of small parts that produce red/green color.

System working gloves chicken tiren detection when consumers want to buy chicken meat to the traditional market, then consumers can detect fresh by touching the chicken meat chicken meat sold by using gloves. Part of the sensor probe is embedded in the form of these gloves will come into contact with meat and transfer the information to a microcontroller to provide information the value of capacitance 
in the form of a different color lights on the indicator. The indicator is red if positive tiren (more value from $1.0008 \mu \mathrm{F}$ ) and green color if not.

\section{Kesimpulan}

The value of capacitance tiren chicken meat all different parts with a capacitance value of fresh chicken meat, chicken meat capacitance value tiren capacitance value is bigger than the fresh chicken meat. Gloves detection detection of chicken meat tiren uses the concept of the bigger value of the capacitance on tiren chicken meat then fresh chicken meat, Indicator is red if positive tiren and green color if not.

\section{Daftar Pustaka}

1. Bisman, Design of Digital Capacitance Meter. Sumatera Utara: Faculty of Mathematics and Natural Sciences, Department of physics Universitas Sumatera Utara (2003).

2. Dwiatmaja, A. Wahyu, Rakhmadi, F. Agun, The Resistance Characteristic of Chicken Meat and Tiren Chicken Meat. Yogyakarta: Faculty of Science and Technology, UIN Sunan Kalijaga (2013).

3. The Ministry of Agriculture, Chicken Meat as Source of Nutritious Food. Directorate General of Livestock and Animal Health (2012).

4. Nurkholis, Review of Islamic Law Against Selling Tiren Chicken (Studies Sase of Chicken Sellers at the Market of Rejomulyo, Semarang). Semarang: Faculty of Shariah, Institut Agama Islam Negeri Walisongo (2009).

5. Rakhmadi, F. Agung dkk, The Characteristic Capacitance Identification of Chicken Meat and Tiren Chicken Meat. Yogyakarta: Faculty of Science and Technology, UIN Sunan Kalijaga (2013).

6. Soeparno, Science and Meat Technology. Yogyakarta: Gadjah Mada University Press (2009). 